\title{
The Influence of Intelligence and Emotional Intelligence on Religious Attitudes and Their Influence on Entrepreneurial Motivation Among Vocational Students During The COVID-19 Pandemic
}

\author{
Gudnanto, Doctoral Program Universitas Negeri Malang, gudnanto@umk.ac.id \\ Andi Mappiarre, Universitas Negeri Malang, andi.mappiare.fip@um.ac.id \\ Adi Atmoko, Universitas Negeri Malang, adi.atmoko.fip@um.ac.id \\ Muslihati, Universitas Negeri Malang, muslihati.fip@um.ac.id
}

\begin{abstract}
The purpose of this study was to determine the effect of intelligence (X1) and emotional intelligence $(\mathrm{X} 2)$ on religious attitudes (Y) and their influence on entrepreneurial motivation (Z) of students during the pandemic. The study was designed with a four-variable path analysis model to determine the relationship between the independent variables and the dependent variables as well as the causal relationship between those variables. The study was conducted on 463 students in pesantrenbased vocational schools. The number of samples was determined by proportional random sampling method based on the Slovin method. The data collection was conducted using a closed scale which was distributed via Google Form media. Meanwhile, specific for intelligence, the data collection utilized the Progressive Matric Standard test. In order to reveal the direct relationship between X1 and X2, and Y to $\mathrm{Z}$, the researchers employed multiple regression analysis with the assistance of SPSS software. The conclusions of this study were (1) there is no positive and significant relationship between intelligence and entrepreneurial motivation; (2) there is a positive and significant relationship between emotional intelligence and entrepreneurial motivation; (3) there is a positive and significant relationship between religious attitudes and entrepreneurial motivation; (4) there is a positive and significant relationship between intelligence and religious attitudes; and (5) there is a positive and significant relationship between emotional intelligence and religious attitudes.

Keywords: intelligence, emotional intelligence, religious attitudes, entrepreneurial motivation

$\begin{array}{lll}\text { Received: 07.11.2020 Accepted: 12.12.2020 Published: 05.01.2021 } & \text { A }\end{array}$
\end{abstract}

\section{INTRODUCTION}

The COVID-19 pandemic has destroyed the entire world order. The whole areas of life from education to the economic sector experience the impacts of this pandemic. The decline in the performance of world economic support countries, such as China, Britain and America, has a domino effect on the world economic downturn [1]. Countries that apply lockdown are even more severely affected since all their economic activities are paralyzed which leads to an impact on all components including psychological and environmental aspects [2]. Countries like Malaysia are starting to rise up by applying technological advances to anticipate communal virus infections and to minimize the economic impacts due to the prolonged lockdown in the country. Their economy, however, is still minus and the recession is getting even worse [3]. A WHO study even showed that the world economic circulation has been completely damaged by the pandemic which has resulted in lockdown policies in various countries [4]. In India, the industrial sector losses even reach 10-30\% of the country's gross domestic product [5]. The socio-economic crisis has transformed investment in the energy sector and affected the energy sector significantly with disruptions in most investment activities due to mobility restrictions [6]. Even so, there are areas of the economy that are still developing. The technology network-based economy is considered to be the least affected sector by this pandemic. YouTube content creators, online and electronic media entrepreneurs and bloggers are considered to have incomes that have not decreased significantly. It is presumed that even the world economy is currently being aided by the development of digital industry [7]. Energy consumption from fossil materials has also decreased by about 0.1 until $0.6 \%$ which has an impact on the decreasing 
levels of air pollution in the world [8]. In India, the reduction in pollution is predicted up to $29 \%$, thereby improving the air quality in that country [9].

Apart from having an economic impact, the education sector is also heavily affected by the pandemic situation. Educational policies force the entire students to change their learning behavior and, in the end, change the attitudes and behavior that they previously carried out routinely. A research in China showed that there are occurrences of many mental disorders such as phobias, learning anxiety, paranoia and interpersonal sensitivity [10]. Another study in the UK also showed that the pandemic causes stress due to mobility constraints because of the prolonged lockdowns [11]. In Vietnam, students and university students are forced to be increasingly sensitive to the crisis that hit their environment a [12]. The social distancing induces boredom to a group of athletic students who are accustomed to interacting in certain groups in learning. It was revealed that the problem of decreasing mental health level of athlete students is due to minimal interaction as a result of social distancing policies [13]. Even in a study on college students in the United States, it was concluded that social distancing is one of the causes of insomnia, depression, anxiety and acute stress in many students [14]. To overcome these problems, distance learning through internet (e-learning) is applied. A study in Jordan showed that e-learning addresses the physical activity problems directly but does not effectively mediate students' learning burnout [15].

The next challenge is how the world of education plays a role in restructuring the debris of the damage caused by the COVID-19 pandemic. The world of education faces the challenge of preparing more resilient human resources in the dealing with any changes that either build up or destroy world stability. Education is expected to be able to answer the preparation of human resources who are capable of restoring the economy both macro and micro from the smallest scale to the global scale. Education must be able to respond and at the same time adapt to the development of artificial intelligence, big data, and the traumatic impact of crisis situations that may occur at any time after the COVID-19 pandemic situation [16]. The education system must be developed to actually include the facilitation of the development and development of the smallest human aspects as well as the impact of a prolonged crisis [17]. Education does not focus only on developing human intelligence, which includes general intelligence, emotional intelligence and special talents, any longer, but must also seek to help facilitate other developmental components such as the possibility of religiosity influence in achieving success and facilitating entrepreneurial motivation in response to the economic problems both now and in the future.

Intelligence is the capacity for logic, understanding, self-awareness, learning, emotional knowledge, reasoning, planning, creativity, critical thinking, and problem solving [18]-[20]. This is related to the cognitive activities of students in the learning process both in terms of process and results. Intelligence always becomes a measure of success because it is in connection with students' problem solving activities. Intelligence does not stand by itself. In successful learning, it is known that it has several links with other types of intelligence such as emotional intelligence and even students' religious attitudes [21]-[24]. In addition, it is especially related to the characteristics of Indonesian people who are wellknown as cultural, spiritual and religious people [25]. As human, students must be treated holistically to obtain optimal results including treating the components of personality, intelligence and psychomotor [26]. In the context of educational psychology, efforts to recognize, facilitate and simultaneously develop cognitive, psychosocial, and behavioral components are required to be contextualized with the surrounding socio-cultural diversity [27]. In a more specific condition, even the researchers' criticism leads more to certain racial identification to help identify the initial psychological readiness and intelligence as the basis of educational programming [28].

Even though intelligence is still the main predictor of the education and learning process in general [29], there are already many criticisms related to the importance of identifying other items that can help the success of education particularly so that the student outcomes can truly become independent individuals who survive in crisis conditions [30]. A study in Bangladesh found that religiosity and spirituality are even part of the supporting abilities to survive in the face of a crisis when education is allegedly dominated by the goal of strengthening cognitive and intelligence aspects [31]. Another study showed that $64 \%$ of trauma due to crisis can be resolved using spiritual and religious approaches [32].

The problem solving challenge during the pandemic is to prepare superior human resources through education to do problem solving economically to survive in life [33], [34]. One of them is identifying students' motivation and entrepreneurial initiation as the basis for designing educational programs that can facilitate these aspects [35], [36]. Entrepreneurial motivation is assumed to have the ability to encourage a student to break out of the dependence on others to meet his economic needs [37], [38] and have the capability of being an answer to the economic downturn due to the pandemic. In the context of education in Indonesia, the system and curriculum prepared to produce skilled workers is a vocational 
school although it does not rule out the possibility of students from other pathways to acquire certain skills to support their lives.

The culture of Indonesian society that is closely related to spirituality and religiosity makes education to be often linked and even obliged to contain the developmental elements of religious and spiritual life as part of soft skills development [39]. Another study even confirms the existence of a linkage of religious entities to the development of students' cognitive and emotional components [40]. Moreover, an earlier study also corroborated the existence of a positive or negative relationship between intelligence and student religiosity [41]. Recent studies, however, have shown a negative relationship, which revealed that most intelligent people have low religiosity. From the analysis, it was identified that there is a moderating variable of analytical thinking skills in this negative relationship [42], [43]. Even so, intellectuality and intelligence which are influenced by emotional conditions are quite influential on human religiosity; hence, it is not wrong if intelligence and emotional intelligence should be developed simultaneously so as not to become a negation of human religiosity [22]. This is in accordance with the opinion of previous experts which stated that the existence of emotional dynamics are influenced by human religiosity [44]. Consequently, when humans face anxiety and trauma due to a pandemic crisis situation, the aspect of religiosity will be the problem solution.

The dynamics of religiosity also affect a person's entrepreneurial motivation. A research showed that religious figures such as Abdurrahman ibn Auf taught important concepts in entrepreneurship as an initial motivation [45]. This becomes one of the reasons why several Arab countries are prominent for their many very wealthy businessmen. Research in the United Arab Emirates showed that there is a great influence of Islamic teachings on the motivation to do entrepreneurship for the people, including women [46]. Another study conducted in the US also found that religiosity can support entrepreneurial success because it is considered capable of overcoming the problems of human life satisfaction and dissatisfaction [47]. These dynamics show that the potential for resource development through the use of religiosity, intelligence, and emotional intelligence is very large and very possible, especially in the context of education as the vanguard of preparing human resources.

Indonesia, with its status as a country with the largest number of Muslims in the world, has great potential to develop an education system by involving and placing components of intelligence, emotional intelligence and religious attitudes for the development of globally competitive human resources. It is definitely not only an incidental effort during a pandemic but also a systematic effort which is expected to be carried out continuously for decades to come. A research showed that Indonesia has the potential to be developed massively because the majority of university students and students in Indonesia have a strong desire to succeed in life [48]. Nevertheless, it was found that the locus of control, achievement motivation, and entrepreneurial desire of university students and students are low [49]. Furthermore, other studies also discovered the same fact, i.e. the majority of university students still doubt the possibility of continuing their life as an entrepreneur and their intention to run a business [50], [51]. Phenomena like this need to be studied further in order to identify the relationship of each variable, the opportunity to moderate the construction and the destruction between variables, as well as the facilitation of the optimal development of each variable.

This phenomena as described need to be studied further, especially in terms of the relationship between intelligence, emotional intelligence, religious attitudes and entrepreneurial motivation. The aim is to arrange educational programs in accordance with the characteristics of these variables in order to achieve the main goals of education. This article will examine the relationship between these variables. After that, the results of the study can be employed to compile an entrepreneurial education curriculum by utilizing intelligence, emotional intelligence and religious attitudes as problem solutions systematically if in the future, a crisis situation like this COVID-19 pandemic occurs.

\section{METHOD}

\section{Design and Research Subjects}

The research was conducted with a quantitative approach to determine the causal relationship between independent and dependent variables. Path analysis was selected to test the causal relationship between variables with a structural equation model. The relationship between the variables is displayed in Figure 1. 


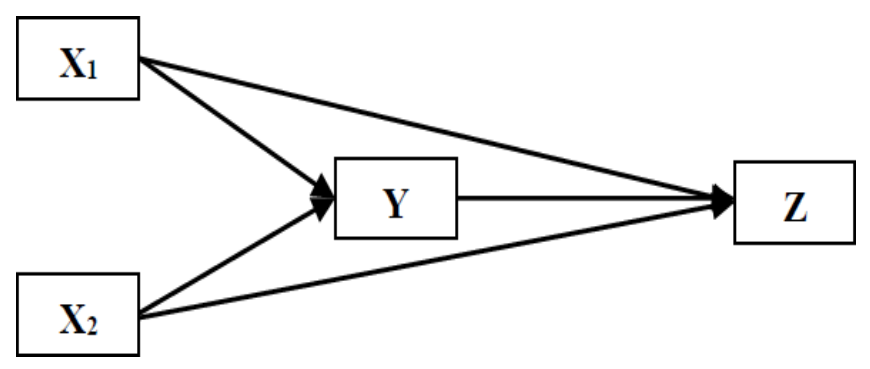

Fig. 1. The relationship between variables $X 1, X 2, Y$ and $Z$

Variable $\mathrm{X} 1$ is general intelligence, $\mathrm{X} 2$ is emotional intelligence, $\mathrm{Y}$ is religious attitudes and variable $\mathrm{Z}$ is resilience of entrepreneurial motivation. The sample was selected by proportional random sampling by taking the distribution and the representation of the whole students of pesantren-based vocational schools in Java into account. The sample studied in this study was 463 students of pesantren-based vocational schools. The reason why students of pesantren-based vocational schools were selected as the subject in this study was based on the fact that pesantren-based vocational schools have three educational systems at once which include skills-oriented vocational education, the national curriculum in accordance with the national standards of education, and pesantren-based religious education. The selected sample was in the age range of 15-18 years who were at the grade XI and XII levels of vocational schools, and consisted of 294 male students (santri) and 169 female students (santriwati). Distribution of the population was from the following regencies and municipalities: 48 respondents from Semarang, 67 respondents from Jombang, 97 respondents from Kudus, 54 respondents from Pati, 68 respondents from Rembang, 27 respondents from Tasikmalaya, 36 respondents from Malang, 17 respondents from Cirebon, 15 respondents from Tuban, 21 respondents from Bantul and 13 respondents from Serang. This distribution of students has represented the entire island of Java which includes Banten, West Java, Central Java, DI Yogyakarta and East Java provinces. The regencies and municipalities selected were based on the fact that they have a large number of Pesantren that simultaneously provide formal education.

\section{Research Instruments}

This study utilized four instruments, i.e. validated Raven Progressive Matric, Emotional Intelligence Scale, Religious Attitude Scale and the Entrepreneurial Motivation Scale. Raven Progressive Matric is an instrument that has been standardized. Therefore, it was implemented by a collaboration between the test licensee with the Laboratory of Psychological Tests and Guidance and Counseling Universitas Muria Kudus, while the three other instruments were pilot tested to 35 pupils and students in Pasuruan Regency, East Java. The validity test was carried out through expert judgment on three psychologists. Meanwhile, the reliability test is presented in Table 1.

Table 1. Reliability Test

\begin{tabular}{|l|l|l|l|l|}
\hline No & Instrument & $\begin{array}{l}\text { Cronbach's } \\
\text { Alpha }\end{array}$ & N of Items & Result \\
\hline 1 & Emotional Intelligence Scale & 0.817 & 41 & Reliable \\
\hline 2 & Religious Attitude Scale & 0.799 & 25 & Reliable \\
\hline 3 & Enterpreunal Motivation Scale & 0.794 & 50 & Reliable \\
\hline
\end{tabular}

Based on Table 1, it is revealed that the entire instruments have been tested for reliability so that they can be consistently utilized in various institutions. As is known, this research was conducted in four institutions in which the possibility of cultural bias is very large. Therefore, the reliability of the instrument must be thoroughly tested in order to obtain consistent data accuracy.

\section{Data analysis}

Descriptive analysis technique was used to describe the data obtained from the research process. The statistical measures that are often used in decision making are (1) looking for a central tendency, such as the mean, median, and mode; and (2) looking for dispersions, such as deviation and variance [53]. The requirements tests employed in path analysis adopted the classic assumption test of regression analysis, which were (1) normality test; (2) linearity test; (3) multicollinearity test; (4) autocorrelation test; and (5) 
heteroscedasticity test. Hypothesis testing to determine the significance of hypothesis testing in path analysis on simultaneous (overall) testing on each sub-structure can be observed from the comparison between the probability value of 0.05 and the probability value of $\mathrm{Sig}$. If the sig value is $<0.05$, the decision that can be taken is that $\mathrm{HO}$ is rejected while $\mathrm{Ha}$ is accepted [54], [55].

\section{RESULT AND DISCUSSION}

In general, the data was obtained from 463 respondents of pesantren-based vocational school students who were spread across the island of Java. Although pesantren are known as traditional religious education institutions, many of them are now starting to modernize the education model by adopting a formal education curriculum from the government to suit the needs of the times. The description and distribution of data obtained by processing the instruments can be observed in Table 2 .

Table 2. Descriptive Statistics

\begin{tabular}{|c|c|c|c|c|c|c|c|c|c|c|}
\hline & $\mathrm{N}$ & Minimum & $\begin{array}{l}\text { Maxim } \\
\text { um }\end{array}$ & Mean & $\begin{array}{l}\text { Std. } \\
\text { Deviation }\end{array}$ & $\begin{array}{l}\text { Varian } \\
\text { ce }\end{array}$ & \multicolumn{2}{|c|}{ Skewness } & \multicolumn{2}{|c|}{ Kurtosis } \\
\hline & $\begin{array}{l}\text { Stati } \\
\text { stic }\end{array}$ & Statistic & $\begin{array}{l}\text { Statisti } \\
\mathrm{c}\end{array}$ & Statistic & Statistic & $\begin{array}{l}\text { Statist } \\
\text { ic }\end{array}$ & $\begin{array}{l}\text { Statist } \\
\text { ic } \\
\end{array}$ & \begin{tabular}{|l|} 
Std. \\
Erro \\
$\mathrm{r}$ \\
\end{tabular} & $\begin{array}{l}\text { Statist } \\
\text { ic }\end{array}$ & \begin{tabular}{|l} 
Std. \\
Erro \\
$\mathrm{r}$ \\
\end{tabular} \\
\hline Intelligence & 463 & 79 & 124 & 103.27 & 7.301 & $\begin{array}{l}53.29 \\
9\end{array}$ & -.540 & .113 & .765 & .226 \\
\hline $\begin{array}{l}\text { Emotional } \\
\text { Intelligence }\end{array}$ & 463 & 66.00 & 133.00 & 97.0108 & 11.08106 & $\begin{array}{l}122.7 \\
90\end{array}$ & .200 & .113 & .977 & .226 \\
\hline $\begin{array}{l}\text { Religious } \\
\text { Attitudes }\end{array}$ & 463 & 55.00 & 95.00 & 75.2030 & 7.87606 & $\begin{array}{l}62.03 \\
2\end{array}$ & .636 & .113 & .175 & .226 \\
\hline $\begin{array}{l}\text { Entrepreneu } \\
\text { rial } \\
\text { Motivation }\end{array}$ & 463 & 104.00 & 185.00 & $\begin{array}{l}138.330 \\
5\end{array}$ & 21.04378 & $\begin{array}{l}442.8 \\
41\end{array}$ & .521 & .113 & -.962 & .226 \\
\hline $\begin{array}{ll}\text { Valid } & \mathrm{N} \\
\text { (listwise) } & \end{array}$ & 463 & & & & & & & & & \\
\hline
\end{tabular}

According to Table 2, it is distinct that the skewness and kurtosis scores on all variables were close to 0 ; thus, it can be considered that the data distribution has been normally distributed. The result of the Variance Inflation Factor test for each variable was around the value of 1, while the tolerance for each variable was close to the value of 1 . This shows that there is no multicollinearity problem between the research variables. The relationship between variables is a one-way flow system. Each variable has been measured using valid instruments and variables. The model has been properly analyzed and identified based on the relevant theories and concepts. After that, testing with 2 model regression analysis was carried out.

\section{Regression Analysis Model 1 (Testing the Relationship of Variables X1, X2 and Y)}

Regression analysis model 1 examined the relationship between intelligence (X1), emotional intelligence (X2) and students' religious attitudes (Y). The results of the R Square test model 1 showed that the value was 0.80 , which means that the contribution of intelligence and emotional intelligence was only $80 \%$ towards religious attitudes, and the remaining $20 \%$ was influenced by other variables outside the study. Furthermore, the analysis of the relationship between variables is described in Table 3 .

Table 3. Regression Test of Variables X1, X2 and $Y$

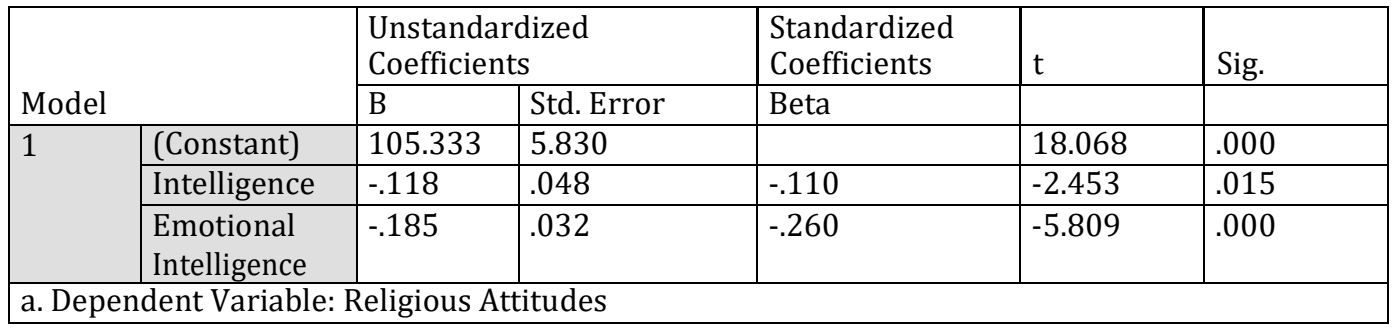


Regression analysis model 1 refers to the results of data analysis in table 3. Based on Table 3, it can be observed that the significance of intelligence variable was $0.015<0.05$, while that of emotional intelligence variable was $0.000<0.05$, which means that the upbringing and emotional intelligence affect interpersonal communication. Meanwhile, the value of $\mathrm{e} 1=\sqrt{1-0.8}=0.44$.

\section{Analisis Regresi Model 2 (Pengujian Hubungan Variabel X1, X2, Y dan Z)}

Regression analysis model 2 examined the relationship between intelligence (X1), emotional intelligence (X2) and students' religious attitudes (Y) and their impact on entrepreneurial motivation (Z). The results of the R Square test model 1 showed that the value was 0.038 , which means that the contribution of intelligence and emotional intelligence was only $3.8 \%$ towards religious attitudes, while the remaining $96.2 \%$ was influenced by other variables outside the study. Furthermore, the analysis of the relationship between variables is described in Table 4.

Table 4. Regression Test Results of Variables X1, X2, Y and $Z$

\begin{tabular}{|c|c|c|c|c|c|c|}
\hline \multirow{2}{*}{\multicolumn{2}{|c|}{ Model }} & \multicolumn{2}{|c|}{ Unstandardized Coefficients } & \multirow{2}{*}{\begin{tabular}{|l} 
Standardi \\
zed \\
Coefficient \\
S \\
Beta \\
\end{tabular}} & \multirow[t]{2}{*}{$\mathrm{t}$} & \multirow[t]{2}{*}{ Sig. } \\
\hline & & B & Std. Error & & & \\
\hline \multirow[t]{4}{*}{1} & (Constant) & 169.958 & 20.790 & & 8.175 & .000 \\
\hline & Intelligence & .011 & .132 & .004 & .081 & .935 \\
\hline & $\begin{array}{l}\text { Emotional } \\
\text { Intelligence }\end{array}$ & .069 & .090 & .037 & .772 & .044 \\
\hline & Religious Attitudes & -.525 & .127 & -.196 & -4.127 & .000 \\
\hline
\end{tabular}

Regression analysis model 2 refers to the results of data analysis in Table 4. According to Table 4, it is identified that significance of intelligence variable was $0.935>0.05$ whereas that of emotional intelligence variable was $0.044<0.05$ and that of religious attitudes was $0.000<0.05$, which means that intelligence has no effect on entrepreneurial motivation while emotional intelligence and religious attitudes affect entrepreneurial motivation. Meanwhile, the value of $\mathrm{e} 1=\sqrt{1-0.038}=0.98$.

\section{DISCUSSION}

The results of this study indicate that there are variables that have an effect and have no effect on students' entrepreneurial motivation. This study informs that intelligence does not contribute to students' entrepreneurial motivation. This means that any high intelligence does not guarantee the success and motivation to build entrepreneurship. These findings are linear to the research which explained that entrepreneurial spirit does not depend on a person's general intelligence [56], [57]. However, it is well known that intelligence and religious attitudes have a positive causal relationship (see table 3). This supports a research by Turner (1980) which discovered this fact. Furthermore, Francis (1998) identified a tendency that students aged 16-17 who have high intelligence and are supported by a good social environment will increase their motivation to learn religion; hence, it will positively affect their religious attitudes. This is because religious culture around students will form emotional dynamics that support the students' ability and motivation to learn religion [40]. It is unmistakable if the model of religious education in Indonesia has always been created in an environment that allows students/santri to get social support from the environment to achieve the desired religious education goals.

Based on Table 3 and Table 4, emotional intelligence has a direct and indirect relationship with students' entrepreneurial motivation. In general, general intelligence is an emotional dynamic that directly affects and is influenced by spiritual and religious attitudes when facing an event that causes anxiety [31], [58]. Furthermore, it is known that emotional intelligence directly affects entrepreneurial motivation. In fact, a person's creativity and motivation is not only influenced by intelligence, but is also influenced by emotional dynamics that occur within him. This means that emotional intelligence that supports emotional stability participates in the growth and development of a person's creativity and motivation, including entrepreneurial motivation [18].

This study also found the fact that students' religious attitudes have a direct influence on students' entrepreneurial motivation. From various experiences of CEOs who have high religiosity, it is suggested that they tend to have an effective leadership style because of having dignity and becoming a role model in 
their commitment to work [59]. The findings of a study in the United States found that religiosity affects entrepreneurial success, whereas wealth-seeking behavior is more on pursuing higher life satisfaction [47]. In addition, A study in Africa even reinforced the fact that the majority of entrepreneurs tend to use religious teaching starting points to carry out problem solving for the business problems they experience [60]. Moreover, other studies in Brazil also found that religious leaders (pastors) exhibit strong entrepreneurial characteristics in carrying out religious missions and church development [61], [62]. Furthermore, another study in India also found that the large investments that have recently entered India are mostly made by people who have religious behavior even by religionists [63]. This fact shows that this result is confirmed positively so that it can be concluded that the higher the religious attitudes of a person, the higher the entrepreneurial motivation is.

The next fact is that religious values are influential and even create new values individually which will contribute to the behavior of Muslim entrepreneurs [64]. Therefore, the formation of a social environment that is adequate to instill religious values will foster entrepreneurial behavior. This is supported by a research in Thailand which found that the basis of entrepreneurial behavior among young people and adolescents there is more on the desire to become more dignified people and the proof of love for the country by contributing to the development of the nation's economic life [56]. Consequently, entrepreneurship education programs must be started at the primary school level by instilling the values of diversity and love for the country in order to increase entrepreneurial motivation for the majority of students.

Entrepreneurial activities have become the answer to macroeconomic problems that are often experienced by countries with large-scale economic capabilities. Entrepreneurial behavior will form green shoots of micro-economic that help sustain the economy of a country. Entrepreneurship education is not only dominated by those in the normal category. Even persons with disabilities are also involved in entrepreneurial activities armed with the religious belief that they must be capable of being successful even though they live with limitations [65]. Most importantly, the education process in schools must have the capability to facilitate the growth and development of optimism, innovation and a spirit of competition that will support the development of entrepreneurial motivation and behavior [66]. Education must also be able to hone the ability to work in teams, creativity and initiation, empathy, and resilience in facing failures as a form of entrepreneurial thinking skills [57]. This opportunity can actually be implemented within the pesantren-based formal education environment which polish formal cognitive abilities and life skills as well as the development of religious insight and behavior simultaneously in developing entrepreneurial motivation and behavior as a support for the nation's life.

\section{CONCLUSION}

Confronting the complexity of problems during a pandemic requires things that are out of the box in order to make one continue to maintain his existence. Entrepreneurial motivation is the answer to this problem because it is considered good at answering economic problems that often arise as a result of the lack of opportunities to work in established companies. This study shows that entrepreneurial ability is directly influenced by religious attitudes and emotional intelligence. For this reason, education in Indonesia must facilitate both of these things simultaneously in order to develop properly and be able to support students' entrepreneurial motivation. In response to this, Indonesia is known as a country which is rich in local wisdom based on religion and culture which can be utilized as a reference and a basis for optimizing the achievement of entrepreneurial education goals as well. Pesantren-based education which simultaneously provides formal education is considered capable of representing a facilitative education program for the development of more competitive human resources in entrepreneurship. Therefore, in the future, education in Indonesia must be improved by adopting the pesantren education system or pesantren education which simultaneously adopts a formal education curriculum system. This is aimed at creating more competitive Indonesian human resources in developing entrepreneurs who are globally competitive.

\section{REFERENCE}

S. Song, "Street Stall Economy in China in the Post-COVID-19 Era : Dilemmas and Regulatory Suggestions," Res. Glob., p. 100030, 2020.

A. Atalan, "Is the lockdown important to prevent the COVID-9 pandemic? Effects on psychology, environment and economy-perspective," Ann. Med. Surg., vol. 56, no. June, pp. 38-42, 2020.

N. A. Aziz, J. Othman, H. Lugova, and A. Suleiman, "Malaysia's approach in handling CoVID-19 onslaught: Report on the Movement Control Order (MCO) and targeted screening to reduce community infection rate and impact on public health and economy," J. Infect. Public Health, 2020. 
T. Ibn-Mohammed et al., "A critical review of the impacts of COVID-19 on the global economy and ecosystems and opportunities for circular economy strategies," Resour. Conserv. Recycl., vol. 164, no. September 2020, p. 105169, 2021.

T. Kanitkar, "The COVID-19 lockdown in India: Impacts on the economy and the power sector," Glob. Transitions, vol. 2, pp. 150-156, 2020.

M. Mofijur et al., "Impact of COVID-19 on the social, economic, environmental and energy domains: Lessons learnt from a global pandemic," Sustain. Prod. Consum., vol. 26, no. September 2020, pp. 343-359, 2020.

M. Hossain, "The effect of the Covid-19 on sharing economy activities," J. Clean. Prod., no. xxxx, p. 124782, 2020.

N. Norouzi, G. Zarazua de Rubens, S. Choubanpishehzafar, and P. Enevoldsen, "When pandemics impact economies and climate change: Exploring the impacts of COVID-19 on oil and electricity demand in China," Energy Res. Soc. Sci., vol. 68, no. June, p. 101654, 2020.

M. R. Keogh-Brown, H. T. Jensen, W. J. Edmunds, and R. D. Smith, "The impact of Covid-19, associated behaviours and policies on the UK economy: A computable general equilibrium model," SSM - Popul. Heal., no. April, p. 100651, 2020.

R. Jiang, "Knowledge, attitudes and mental health of university students during the COVID-19 pandemic in China," Child. Youth Serv. Rev., vol. 119, no. 1318, p. 105494, 2020.

M. J. Savage et al., "Mental health and movement behaviour during the COVID-19 pandemic in UK university students: Prospective cohort study," Ment. Health Phys. Act., vol. 19, no. June, p. 100357, 2020.

D. Van Nguyen, G. H. Pham, and D. N. Nguyen, "Impact of the Covid-19 pandemic on perceptions and behaviors of university students in Vietnam," Data Br., vol. 31, p. 105880, 2020.

S. Graupensperger, A. J. Benson, J. R. Kilmer, and M. B. Evans, "Social (Un)distancing: Teammate Interactions, Athletic Identity, and Mental Health of Student-Athletes During the COVID-19 Pandemic," J. Adolesc. Heal., vol. 67, no. 5, pp. 662-670, 2020.

B. Marroquín, V. Vine, and R. Morgan, "Mental health during the COVID-19 pandemic: Effects of stay-athome policies, social distancing behavior, and social resources," Psychiatry Res., vol. 293, no. August, p. $113419,2020$.

M. Al-Okaily, H. Alqudah, A. Matar, A. Lutfi, and A. Taamneh, "Dataset on the Acceptance of e-learning System among Universities Students' under the COVID-19 Pandemic Conditions," Data Br., vol. 32, p. $106176,2020$.

Y. K. Dwivedi et al., "Impact of COVID-19 pandemic on information management research and practice: Transforming education, work and life," Int. J. Inf. Manage., vol. 55, no. July, p. 102211, 2020.

G. X. Wang et al., "Opportunities for Radiology Trainee Education Amid the COVID-19 Pandemic: Lessons From an Academic Breast Imaging Program," Acad. Radiol., no. Table 2, 2020.

F. Şahin, "General intelligence, emotional intelligence and academic knowledge as predictors of creativity domains: A study of gifted students," Cogent Educ., vol. 3, no. 1, pp. 1-16, 2016.

P. E. Langford, Vygotsky's Developmental and. New York: Psychology Press, 2005.

N. S. Shadrin, "The Problem of Behavioral Determination and Self-Determination in Cultural-Historical and Existential Psychology," J. Russ. East Eur. Psychol., vol. 51, no. 4, pp. 44-66, 2013.

E. B. Turner, "General Cognitive Ability and Religious Attitudes in Two School Systems," Br. J. Relig. Educ., vol. 2, no. 4, pp. 136-141, 1980.

P. Goldie, "Intellectual Emotions and Religious Emotions," in Faith, Rationality, and the Passions, S. Coakley, Ed. New York: Blackwell Publishing Ltd, 2012, pp. 241-249.

G. Rossiter, "Historical perspective on spiritual education in Australian schools Part II: A personal development basis," J. Christ. Educ., vol. 54, no. 3, pp. 15-27, 2011.

A. Sen, "Dharma Concepts in Emotional," Vision, vol. 16, no. 2, pp. 93-99, 2012.

Zubaedi, Desain Pendidikan Karakter: Konsepsi dan Aplikasinya dalam Lembaga Pendidikan. Jakarta: Kencana, 2015.

J. Feist and G. J. Feist, Theories of Personality. Boston: McGraw Hill, 2006.

J. W. Santrock, Educational Psychology, vol. 15. McGraw-Hill, 2017.

D. Gillborn and G. Ladson-Billings, "Education and critical race theory," in The Routledge International Handbook of the Sociology of Education, M. W. Apple, S. J. Ball, and L. A. Gandin, Eds. New York and London: Routledge Taylor \& Francis, 2010.

N. Paz-Baruch, "Educational and learning capital as predictors of general intelligence and scholastic achievements," High Abil. Stud., vol. 31, no. 1, pp. 75-91, 2020.

Z. Selden, "The General Intelligence Division: J. Edgar Hoover and the Critical Juncture of 1919," Int. J. Intell. CounterIntelligence, vol. 0, no. 0, pp. 1-16, 2020.

M. E. Uddin, "Religious attitude, religiosity, and arrack drinking patterns among Muslim, Hindu, Santal, and 
Oraon communities in Rasulpur Union, Bangladesh," Int. Q. Community Health Educ., vol. 28, no. 4, pp. 351-370, 2007.

I. Marini and N. M. Glover-Graf, "Religiosity and spirituality among persons with spinal cord injury: Attitudes, beliefs, and practices," Rehabil. Couns. Bull., vol. 54, no. 2, pp. 82-92, 2011.

Y. Siriwardhana, G. Gür, M. Ylianttila, and M. Liyanage, "The role of 5G for digital healthcare against COVID19 pandemic : Opportunities and challenges," ICT Express, no. xxxx, 2020.

F. Aziz et al., "The care of kidney transplant recipients during a global pandemic: Challenges and strategies for success," Transplant. Rev., vol. 34, no. 4, p. 100567, 2020.

A. M. Wijaya, Tony; Nurhadi; Kuncoro, "Intensi Berwirausaha Mahasiswa : Perspektif Pengambilan Risiko," Siasat Bisnis, vol. 19, no. 2, pp. 109-123, 2015.

J. G. Frynas, M. J. Mol, and K. Mellahi, "Management innovation made in China: Haier's Rendanheyi," Calif. Manage. Rev., vol. 61, no. 1, pp. 71-93, 2018.

L. Gundry, J. Kickul, H. Welsch, and M. Posig, "Technological Innovation in Women-Owned Firms: Influence of Entrepreneurial Motivation and Strategic Intention," Int. J. Entrep. Innov., vol. 4, no. 4, pp. 265274, 2003.

S. S. Khanka, "Motivational orientation of assamese entrepreneurs in the SME sector," J. Entrep., vol. 18, no. 2, pp. 209-218, 2009.

S. Utaminingsih, S. Utomo, and E. Zamroni, "Strengthening of Indonesian Islamic Character Though Islamic Education Management Based of Soft Skills," Addin, vol. 11, no. 1, p. 215, 2017.

J. Dulin, "How emotion shapes religious cultures: A synthesis of cognitive theories of religion and emotion theory," Cult. Psychol., vol. 17, no. 2, pp. 223-240, 2011.

L. J. Francis, "The relationship between intelligence and religiosity among 15-16-year-olds," Ment. Health. Relig. Cult., vol. 1, no. 2, pp. 185-196, 1998.

M. Zuckerman, C. Li, S. Lin, and J. A. Hall, "The Negative Intelligence-Religiosity Relation: New and Confirming Evidence," Personal. Soc. Psychol. Bull., vol. 46, no. 6, pp. 856-868, 2020.

M. Zuckerman, J. Silberman, and J. A. Hall, "The Relation Between Intelligence and Religiosity: A MetaAnalysis and Some Proposed Explanations," Personal. Soc. Psychol. Rev., vol. 17, no. 4, pp. 325-354, 2013.

F. N. Watts, "Psychological and Religious Perspectives on Emotion," Zygon®, vol. 32, no. 2, pp. 243-260, 1997.

M. Muliana, "Konsep Dakwah Entrepreneur Menurut Abdurrahman Bin Auf," Al-Idarah J. Manaj. dan Adm. Islam, vol. 1, no. 2, p. 227, 2017.

H. A. Tlaiss, "Entrepreneurial motivations of women: Evidence from the United Arab Emirates," Int. Small Bus. J. Res. Entrep., vol. 33, no. 5, pp. 562-581, 2015.

R. R. Bellu and P. Fiume, "Religiosity and Entrepreneurial Behaviour an Exploratory Study," Int. J. Entrep. Innov., vol. 5, no. 3, pp. 191-201, 2004.

D. Dainuri, "Kontribusi Pendidikan Entrepreneurship: Suatu Upaya Konstruktif Menumbuhkan Jiwa Wirausaha Pada Mahasiswa," J. Sharia Econ., vol. 1, no. 1, pp. 1-13, 2019.

S. Mulyono, "Locus of Control, Motivasi Berprestasi Dan Sifat Jiwa Wirausaha Pada Mahasiswa Its," J. Sos. Hum., vol. 2, no. 2, pp. 121-132, 2009.

A. A. Vilathuvahna and T. R. D. A. Nugroho, "Intensi Kewirausahaan Mahasiswa Universitas Trunojoyo Madura," Agriekonomika, vol. 4, pp. 107-119, 2015.

D. R. Hidayati and Setiani, "Faktor Pembeda Implementasi Bisnis Berkelanjutan (Sustainable Business) Pada Wirausaha Mahasiswa Universitas Trunojoyo Madura," J. Sos. Ekon. dan Kebijak. Pertan., vol. 7, no. 2, pp. 176-187, 2018.

J. W. Creswell and J. D. Creswell, Research Design Qualitative, Quantitative, and Mixed Methods Approaches. 2018.

Sugiyono, Metode Penelitian Pendidikan. Bandung: Alfabeta, 2015.

Sudjana, Metode Statistika. Jakarta: Tarsito, 2002.

Sugiyono, Metode Penelitian Administrasi. Bandung: Alfabeta, 2013.

K. Wongphuka, T. Chai-Aroon, S. Phainoi, and P. Boon-Long, "Social entrepreneur competencies of social activists involved with children and youths: A case study of Nan province, Thailand," Kasetsart J. Soc. Sci., vol. 38, no. 2, pp. 143-149, 2017.

H. Peschl, C. Deng, and N. Larson, "Entrepreneurial thinking: A signature pedagogy for an uncertain 21st century," Int. J. Manag. Educ., no. xxxx, p. 100427, 2020.

D. Kaur, M. Sambasivan, and N. Kumar, "Effect of spiritual intelligence, emotional intelligence, psychological ownership and burnout on caring behaviour of nurses: A cross-sectional study," J. Clin. Nurs., vol. 22, no. 21-22, pp. 3192-3202, 2013.

F. Toney and M. Oster, "The Leader and Religious Faith The relationship between the exercise of religious 
faith by CEOs, and goal achievement, self-fulfillment, and social benefits," J. Leadersh. Stud., vol. 5, no. 1 , pp. $135-147,1998$.

R. Namatovu, S. Dawa, A. Adewale, and F. Mulira, "Religious Beliefs and Entrepreneurial Behaviors in Africa: A Case Study of the Informal Sector in Uganda," Africa J. Manag., vol. 4, no. 3, pp. 259-281,2018.

V.S. Corrêa, G. M. V. Vale, and M. de A. Cruz, "Entrepreneurial orientation and religion: the Pastor as an entrepreneur," Rev. Adm., vol. 52, no. 3, pp. 330-340, 2017.

T. W. Ferguson, K. D. Dougherty, and M. J. Neubert, "Religious Orthodoxy and Entrepreneurial Risk-Taking," Sociol. Focus, vol. 47, no. 1, pp. 32-44, 2014.

C. Li, Y. Xu, A. Gill, Z. A. Haider, and Y. Wang, "Religious beliefs, socially responsible investment, and cost of debt: Evidence from entrepreneurial firms in India," Emerg. Mark. Rev., vol. 38, no. November 2018, pp. 102-114, 2019.

D. Gursoy, L. Altinay, and A. Kenebayeva, "Religiosity and entrepreneurship behaviours," Int. J. Hosp. Manag., vol. 67, no. June, pp. 87-94, 2017.

D. R. Johnmark, T. Wummen Soemunti, O. Laura, J. C. Munene, and W. Balunywa, "Disabled students' entrepreneurial action: The role of religious beliefs," Cogent Bus. Manag., vol. 3, no. 1, 2016.

R. N. Pitt, L. A. Satcher, and A. M. Drew, "Optimism, Innovativeness, and Competitiveness: The Relationship between Entrepreneurial Orientations and the Development of Science Identity in Scientists," Soc. Curr., vol. 7, no. 2, pp. 155-172, 2020. 